\title{
Hydrological inferences through morphometric analysis of lower Kosi river basin of India for water resource management based on remote sensing data
}

\author{
Praveen Kumar Rai ${ }^{1} \cdot$ Rajeev Singh Chandel ${ }^{1} \cdot$ Varun Narayan Mishra ${ }^{2} \cdot$ Prafull Singh $^{3}$
}

Received: 4 January 2017 / Accepted: 28 December 2017 / Published online: 24 January 2018

(c) The Author(s) 2018. This article is an open access publication

\begin{abstract}
Satellite based remote sensing technology has proven to be an effectual tool in analysis of drainage networks, study of surface morphological features and their correlation with groundwater management prospect at basin level. The present study highlights the effectiveness and advantage of remote sensing and GIS-based analysis for quantitative and qualitative assessment of flood plain region of lower Kosi river basin based on morphometric analysis. In this study, ASTER DEM is used to extract the vital hydrological parameters of lower Kosi river basin in ARC GIS software. Morphometric parameters, e.g., stream order, stream length, bifurcation ratio, drainage density, drainage frequency, drainage texture, form factor, circularity ratio, elongation ratio, etc., have been calculated for the Kosi basin and their hydrological inferences were discussed. Most of the morphometric parameters such as bifurcation ratio, drainage density, drainage frequency, drainage texture concluded that basin has good prospect for water management program for various purposes and also generated data base that can provide scientific information for site selection of water-harvesting structures and flood management activities in the basin. Land use land cover (LULC) of the basin were also prepared from Landsat data of 2005, 2010 and 2015 to assess the change in dynamic of the basin and these layers are very noteworthy for further watershed prioritization.
\end{abstract}

Keywords Remote sensing $\cdot$ GIS $\cdot$ Morphometry $\cdot$ ASTER-DEM $\cdot$ Landsat $\cdot$ Kosi basin

\section{Introduction}

River basins are the fundamental units of the fluvial landscape and a great amount of study has emphasized on their geometric physiognomies including the relationship of the stream networks and quantifiable explanation of hydrological parameters (Abrahams 1984; Huggett and Cheesman 2002). Hydrological parameters are utmost substantial methodical tools for water resource management and valuation in a river basin. Its studies are vital in semi-arid and arid areas of India for protecting the inadequate water resources, because at

Praveen Kumar Rai

rai.vns82@gmail.com

1 Department of Geography, Institute of Science, Banaras Hindu University, Varanasi, UP 221005, India

2 Department of Physics, Indian Institute of Technology (BHU), Varanasi 221005, India

3 Amity Institute of Geo-Informatics and Remote Sensing, Amity University, Sector- 125, Noida, UP 201303, India many places, surface water sources are threatened and at some areas it is completely absent (Sreedevi et al. 2013). River basins encompass a discrete morphologic area and are specifically pertinent to streams pattern and geomorphology of the area (Strahler 1957). It is seen that the geology, elevation and climate are the key components of dynamic ecosystems of water working at the basin scale (Mesa 2006). The progress of river system its flowing pattern over space and time are associated by numerous factors of geology, geomorphology, soil and foliage of the basin area through which river flows. The drainage patterns reflect the surface expressions of the variables persuading river dynamics. The interrelationship between morphometric parameters differs from one river basin to another basin under varied topographical and climatic condition. Understanding these relationships would enable us to recognize the dominant variables acting on a particular river basin (Samal et al. 2015). Hence the fluvial geomorphology is essentially connected with the river basin geometry and its channel network.

Initially, very important and innovative research work on the river morphometry has been completed by Horton (1932, 
1945), Miller (1953), Smith (1950), Strahler (1964) and others. These techniques have been deliberated by a number of researchers on varied geographical areas of India. Some of the fascinating researches on morphometric evolution using satellite data were also completed by Nautiyal (1994), Srivastava (1997), Nag (1998), Srinivasa et al. (2004), Ali et al. (2017) and Rai et al. (2017b). More recently, Singh et al. (2013, 2014), Sreedevi et al. (2005, 2009, 2013), Rai et al. (2014), Rai et al. (2017a, b), Banerjee et al. (2015) and Asode et al. (2016) have calculated morphometric analysis for Indian rivers using DEM data and GIS.

Before emerging GIS and remote sensing technologies, identification of drainage systems within basins or sub basins can be attained using conventional approaches and topographic maps (Verstappen 1983; Mark 1983; O'Callaghan and Mark 1984; Rinaldo et al. 1998; Macka 2001). Nowadays, latest technologies are effectively utilized to develop significantly accurate pictures of several watershed delineation (Ozdemir and Bird 2009). Collectively, these technologies appear dignified to make a better impact on land resource management initiatives, monitoring LULC mapping and change detection in humid or arid or semi-arid regions is experiencing severe stresses due to the collective effects of population growth and climate changes in any river basin area (Singh et al. 2012).

The landform processes, soil physical properties, and erosional characteristics are substantial elements in shaping the peculiarity of watersheds or sub-watersheds can be best assessed through comparing their morphometric parameters (Dar et al. 2013) and its impact on LULC of the basin. RS and GIS are cost-effective tools for assessing the hydrological influences on spatial-temporal changes in LULC (Hathout 2002; Herold et al. 2003; Lambin et al. 2003; Singh et al. 2014). It produces the valuable information to facilitate proper planning and decisions making ability (Franklin 2001) and provides valuable multi-temporal satellite data to analyses the processes land cover change, and GIS provides convenient methods for mapping and evaluating these patterns (Singh et al. 2014).

With a view to having a systematic study of the lower Kosi basin, an attempt has been made in the manuscript to analyses the significant aspects of the morphometry development of the lower Kosi basin and LULC changes in the basin area.

\section{Study area}

The study area is lower Kosi basin covering $6698.50 \mathrm{~km}^{2}$ area. The Kosi river is an oldest rivers of India which initiated at height of about $7000 \mathrm{~m}$ above mean sea level (MSL) in the Nepal Himalayas and also famous for being a biggest tributaries of the Ganga river. The Kosi river drains the northern slopes of the Himalayas in the Tibet Autonomous
Region and the southern slopes in Nepal Himalaya. Highest peaks Mount Everest and Kanchenjunga peak come under its upper catchments and its valley is confined by steep boundaries that separate it from the Yarlung Zangbo river to the north, the Mahananda river to the east, the Gandaki to the west and the Ganga to the south. The Kosi river is flowing across different district, i.e., Madhepura, Supaul, Saharsa, Khagaria, Purnia and Araria in Bihar state of India and meets the Ganga river in Katihar's Kursela, Bihar, India $\left(25^{\circ} 24^{\prime} 43^{\prime \prime} \mathrm{N}\right.$ latitude and $87^{\circ} 15^{\prime} 32^{\prime \prime} \mathrm{E}$ longitude). The total flowing distance between its origin point in the Himalayas and its merger point in the Ganga river in Kursela is around $468 \mathrm{~km}$. The total channel length of the Kosi river is $720 \mathrm{~km}$ long and its total basin area is about $74,500 \mathrm{~km}^{2}$ in Tibet, Nepal and Bihar (India). Location of the Kosi river basin is displayed in Fig. 1.

The Kosi river, with distinctive geomorphology and hydrological characteristics contain a very active regime and very high sediment load. It has long been known as a problematic river and also called as the sorrow of North Bihar due to widespread flooding and recurrent changes in its courses. It is a distinctive braided river, characterized by rapid shifting of bed materials. When in flood, it enters the plain with high velocity and excesses its bank heavily charges with silt and sand. Its flood water rushes over the surface of the country choking the well and driving the villager from their homesteads. It has several epochs covered the settlements with heaps of sand. It pours such a huge quantity of detritus into the Ganga river that long islands are heaped up and swept away in a few hours and the latter becomes unnavigable near its junction (Singh and Singh 1973).

The Kosi alluvial fan extends from Barahkșetra across Nepalese territory, covering northeast Bihar and eastern Mithila to the Ganges, $180 \mathrm{~km}$ long and $150 \mathrm{~km}$ wide which shows a sign of lateral channel fluctuating increasing about $120 \mathrm{~km}$ during the past 250 years. The river, which flowed near Purnia in the eighteenth century, now flows west of Saharsa. Several researchers identified that the Kosi river course has been shifted more than $133 \mathrm{~km}$ from east to west during the last 200 years (Chakraborty et al. 2010).

\section{Data used and methodology}

This work is mainly based on the assessing the hydrological influence from Kosi basin for water resource management by morphometric evaluation and changes of LULC in the area. The Kosi basin boundary and drainage network was extracted through ASTER-DEM data. Furthermore, it has been used to calculate slope and aspect maps. LULC of the basin area was analyzed using multi-temporal Landsat series satellite data of 2005, 2010 (TM) and 2015 (ETM+) with $30 \mathrm{~m}$ spatial resolution (Fig. 2). The remote sensing 


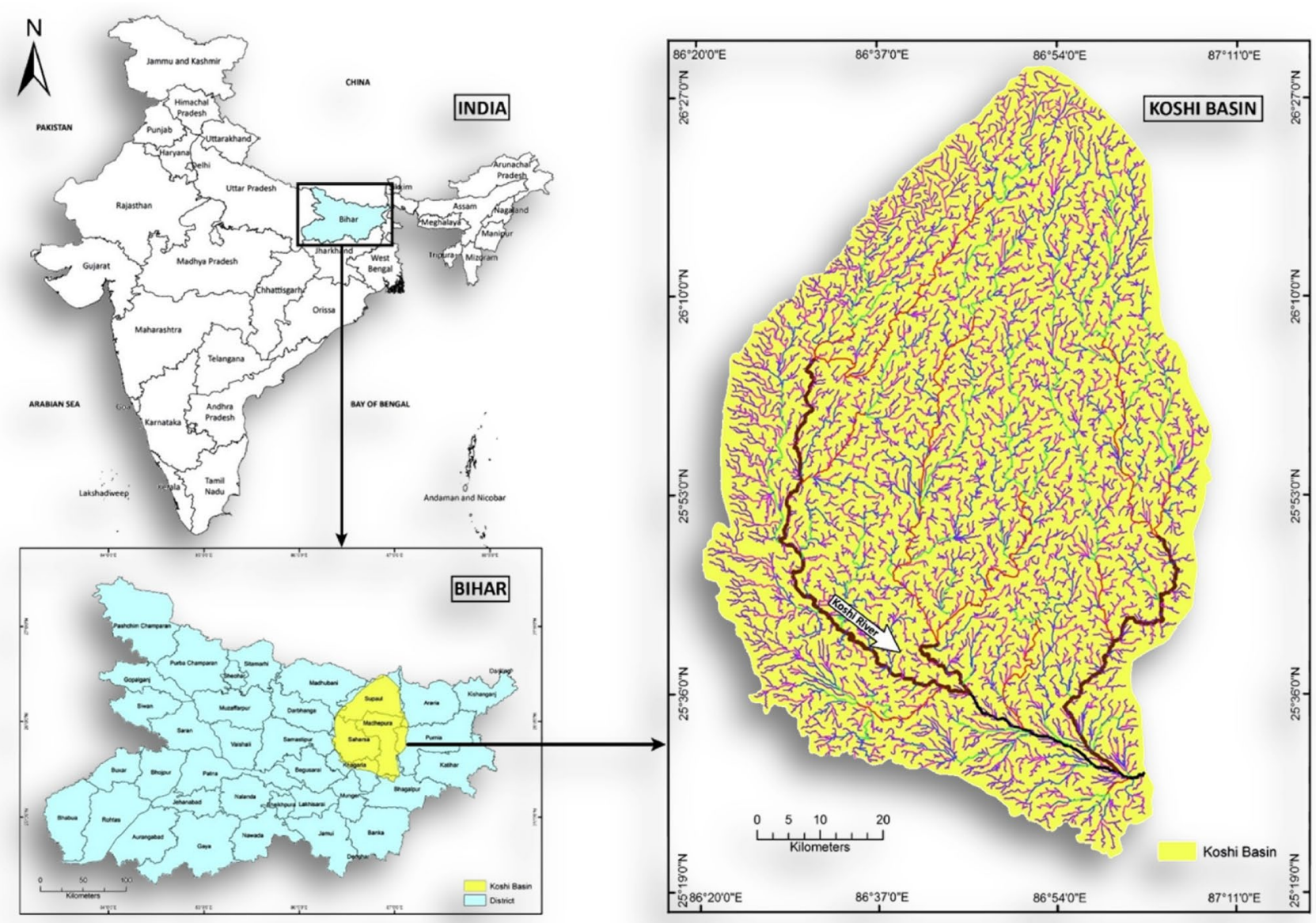

Fig. 1 Location map of lower Kosi basin in Bihar (India)

data were acquired from the USGS website (http://www. earthexplorer.usgs.gov). Google earth images are also used for the cross verification of outcomes of the Landsat data.

The development of stream networks depends on geology, rainfall of the area. The basin demarcation and the related hydrological analysis of streams have been done in Arc GIS 10.3 software. Flow chart of hydrological processes is given in Fig. 3. The basin was also divided into two watersheds for the analysis. Linear, areal and relief aspects of the morphometric parameters were calculated in the study. These parameters were prepared from the streams extracted through ASTER DEM data with the help of spatial analyst tools. Selected morphometric parameters, i.e., drainage density, bifurcation ratio, drainage frequency, circulatory ratio, elongation ratio, etc., has been calculated through the already derived mathematical formulae. Earlier, Horton (1945), Schumm (1956), Strahler (1964), etc., stream ordering methods have been successfully applied for the characterization of watershed and drainage network. The methodology employed to determine the morphometric parameters and its outcomes are given in Table 1.
A supervised maximum likelihood classification technique has been used to produce LULC maps using training sets (signatures) provided by the user based on his field knowledge in the ERDAS Imagine-2013 software. Ground verification was done for doubtful classes during the field survey through hand held GPS (Trimble Juno-3B) and misclassified pixels were rectified using recode option available in the software. In the present study eight major LULC types are identified and classified, i.e., (i) settlement, (ii) vegetation cover, (iii) cultivable land, (iv) fallow land, (v) waste land, (vi) water bodies, (vii) sand bar, (viii) road network. The methodology of LULC processes are shown in Fig. 4. A change matrix (Weng 2001) is also produced in ERDAS Imagine 2013 software (Table 4).

The overall accuracies of classified outputs were evaluated by adding the number of sampled accurately classified pixels divided by the total number of sampled pixels. Furthermore, both overall kappa (accompanied by its variance) and class estimated kappa coefficients were also evaluated. 
Fig. 2 Remote sensing data of the Kosi basin a ASTER DEM, b landsat TM data, 2005, c landsat TM data of $2010, \mathbf{d}$ landsat ETM+ data of 2015
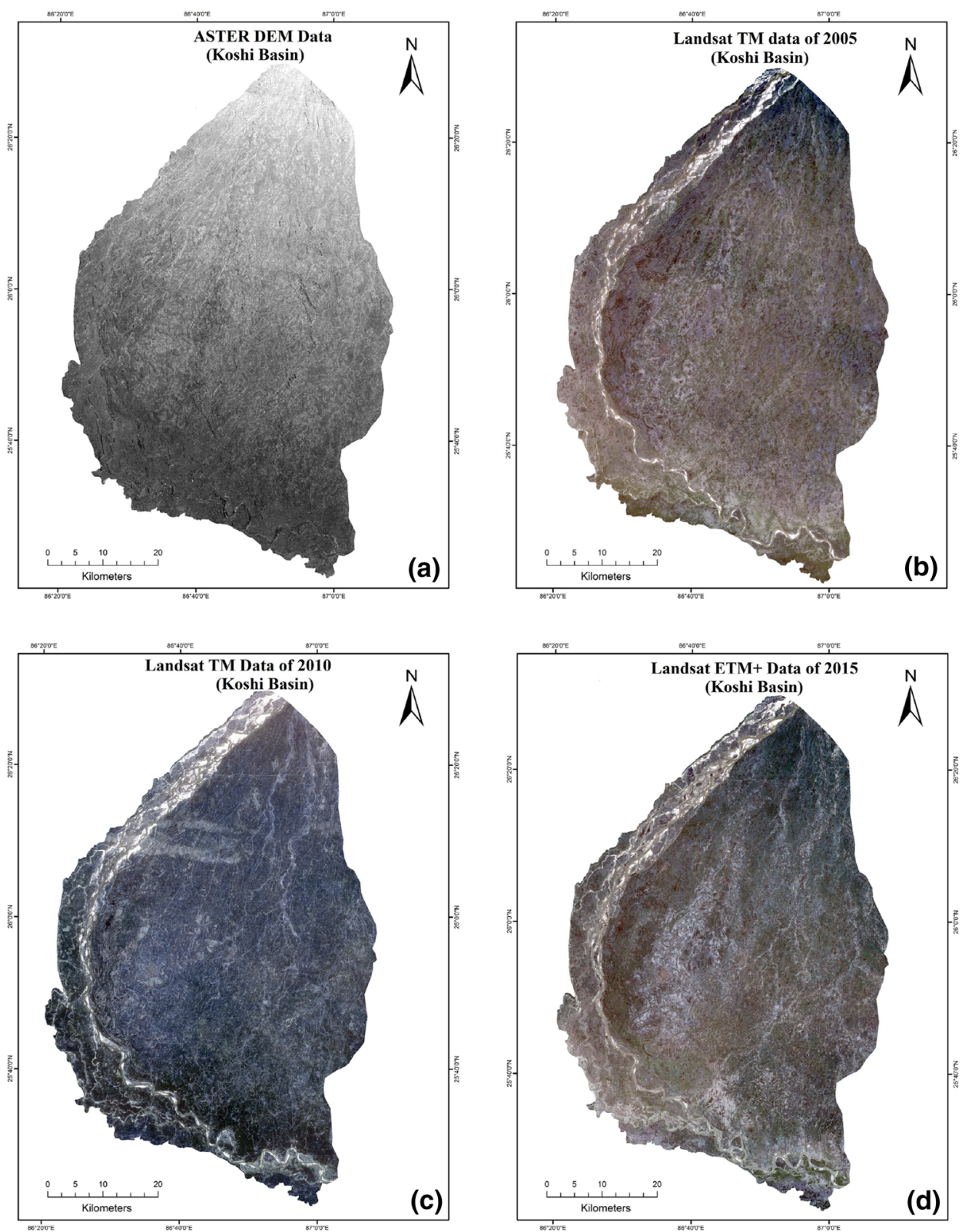

\section{Results and discussion}

The Kosi basin and its drainage network with stream order are presented in Fig. 5a. The estimated morphometric factors were classified as linear, areal and relief parameters (Table 2). During the study, to comprehend the drainage characteristics of the basin area, its morphometry influences on the hydrology was very well studied because these parameters directly affects the size of the extents of peak and mean runoff, whereby the maximum flood discharge per unit area is inversely associated to size (Chorley et al. 1957).

\section{Drainage network analysis or linear aspect of Kosi basin}

Linear parameters of the study area is closely related to the channel patterns of the stream network in which the topographical physiognomies of the stream segments in terms of open relations of the drainage system are studied.

\section{Stream order (So)}

Stream ordering is the main process for basin analysis. In this study, Strahler's (1952) stream ordering scheme 
Fig. 3 Flow chart of hydrological processes of Kosi basin

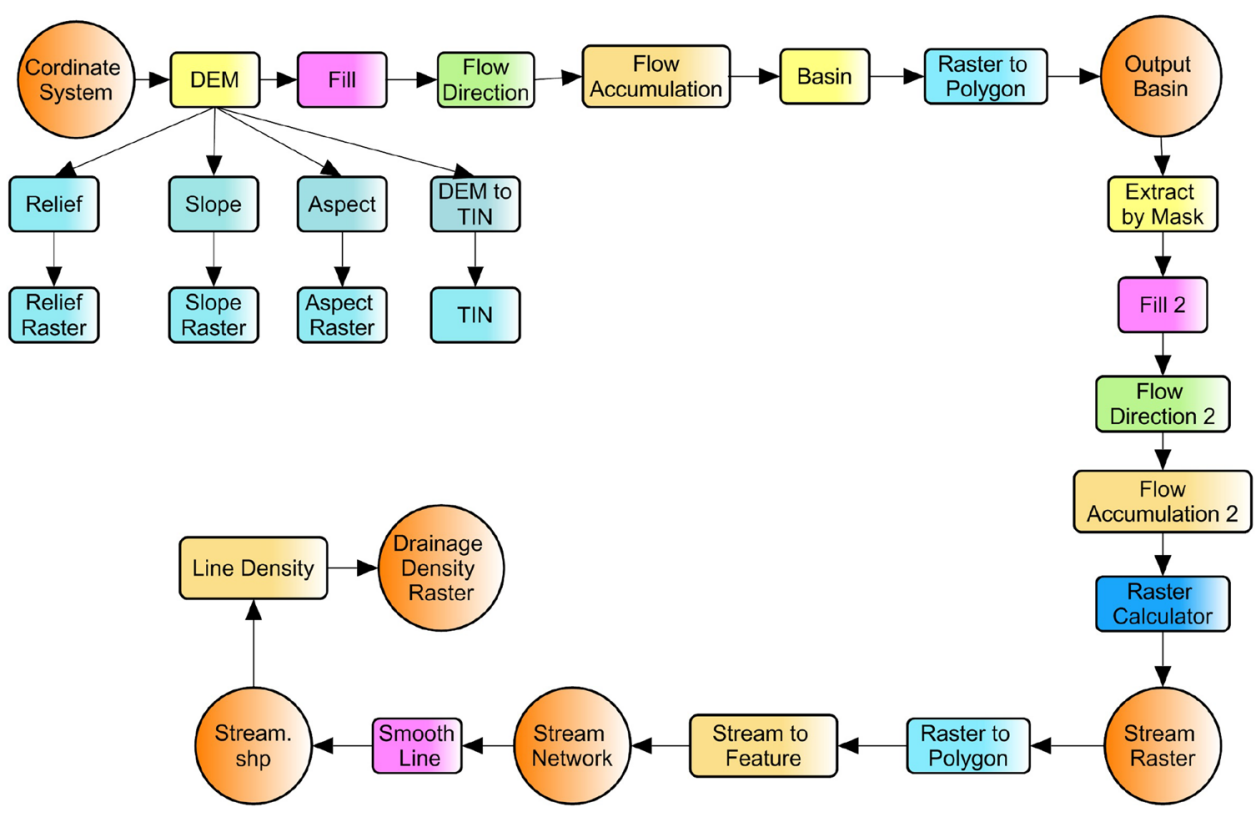

is used and based on stream order, the whole is classified as an seven basin-order (Fig. 5a) with a stream length (7th order) of $195.97 \mathrm{~km}$, and perimeter of $374.053 \mathrm{~km}$. It is noticeably seen that the maximum stream frequency (Sf) is in the case of first order streams (Fig. 5a) and also perceived that decrease in 'Sf' as the stream order increases. Physiography and structural condition of the study area are the significant factors persuading the number and streams order.

\section{Stream number $(\mathrm{Nu})$}

The total numbers of stream in one segment are identified as stream number. It is an utmost significant hydrological character of the basin area as it provides substantial information about surface runoff factors. The river of fairly smaller length is physiognomies of regions with steep gradients and better textures. Horton (1945) says that the numbers of stream sections of each order form an inverse geometric sequence with stream order number (Table 2).

The 'Nu' of each order and the total stream numbers in the basin were calculated in GIS domain (Fig. 4 and Table 2). Total stream numbers in the study area is 6583 including the Kosi river, in that 4038 streams are first order, 1873, 515, 116, 34, 6 and 1 are second, third, fourth, fifth, sixth and seventh order streams, respectively. The first order streams account for $61.33 \%$ of the total stream numbers in the basin area. The maximum numbers of first order streams designate the intensity of permeability and infiltration characteristics of the area.

\section{Stream length (Lu)}

Stream length $(\mathrm{Lu})$ is a significant hydrological parameter of the any river basin as it divulges surface runoff characteristics of comparatively smaller drainage lengths and characteristics of larger gradients area and finer textures. The total 'Lu' of the basin have various 'So', which were computed in GIS platform. Longer ' $\mathrm{Lu}$ ' are usually revealing of gentle slopes. Normally, the total length of stream segments is higher in first order streams and decreases in the higher order stream. Then, after adding each stream for a given order, the total length of stream of each order $(\mathrm{Lu})$ is calculated.

There are total of $7243.82 \mathrm{~km}$ length of stream networks extracted from ASTER DEM data, out of which $3536.89 \mathrm{~km}$ $(48.82 \%)$ is first order, $1773.04 \mathrm{~km}(24.47 \%), 879.06 \mathrm{~km}$ $(12.13 \%), 537.97 \mathrm{~km}(7.42 \%), 309.67 \mathrm{~km}(4.23 \%)$, $171.84 \mathrm{~km}(2.37 \%)$ and $35.35 \mathrm{~km}(0.48 \%)$ are second, third, fourth, fifth, sixth and seventh, respectively. Validation of Horton's law of 'Nu' and 'Lu' favors the concept of geometrical similarity maintained usually in the basin or watershed of increasing stream order (Strahler 1957).

\section{Mean stream length (Lum)}

The 'Lum' is a dimensional parameter which reveals the characteristics and size of a stream segment components and its contributing watershed surfaces (Strahler 1964) and acquired by dividing the total stream length of an order by total number of stream segments in the subsequent order. The 'Lum' values of the basin vary from 0.87 to 35.35 . This

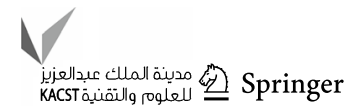


Table 1 Morphometric analysis of Kosi basin-a comparative characteristic

\begin{tabular}{|c|c|c|c|c|}
\hline S. no. & Morphometric parameter & Formula & References & Result \\
\hline A. & Drainage network & & & \\
\hline 1 & Stream order (So) & Hierarchical rank & Strahler (1952) & $1-7$ \\
\hline 2 & First order stream (Sof) & Suf $=\mathrm{Nl}$ & Strahler (1952) & 4038 \\
\hline 3 & Stream number $(\mathrm{Nu})$ & $\mathrm{Nu}=\mathrm{N} 1+\mathrm{N} 2+\cdots+\mathrm{Nn}$ & Horton (1945) & 7411 \\
\hline 4 & Stream length $(\mathrm{Lu}), \mathrm{km}$ & $\mathrm{Lu}=\mathrm{L} 1+\mathrm{L} 2+\cdots+\mathrm{Ln}$ & Strahler (1964) & 7243.82 \\
\hline 5 & Stream length ratio (Lur) & & Strahler (1964) & $0.87-35.35$ \\
\hline 6 & Mean stream length ratio (Lurm) & & Horton (1945) & $0.97 \mathrm{~km}$ \\
\hline 7 & Weighted mean stream length ratio (Luwm) & & Horton (1945) & 1.032 \\
\hline 8 & Bifurcation ratio $(\mathrm{Rb})$ & & Strahler (1964) & $2.15-6.0$ \\
\hline 9 & Mean bifurcation ratio (Rbm) & & Strahler (1964) & 4.20 \\
\hline 10 & Weighted mean bifurcation ratio (Rbwm) & - & Strahler (1952) & 2.045 \\
\hline 11 & Main channel length $(\mathrm{Cl}), \mathrm{km}$ & GIS software analysis & - & $171.58 \mathrm{~km}$ \\
\hline 12 & Valley length (VI), km & GIS software analysis & - & 102.27 \\
\hline 14 & Channel index $(\mathrm{Ci})$ & $\mathrm{Ci}=\mathrm{Cl} / \mathrm{Adm}(\mathrm{H} \& \mathrm{TS})$ & Miller (1953) & 171.58 \\
\hline 15 & Valley index (Vi) & $\mathrm{Vi}=\mathrm{VI} / \mathrm{Adm}(\mathrm{TS})$ & Miller (1953) & 108.27 \\
\hline 16 & Rho coefficient $(p)$ & $p=\mathrm{Lur} / \mathrm{Rb}$ & Horton (1945) & 0.406 \\
\hline B. & Basin geometry & & & \\
\hline 17 & Basin length (Lb), km & GIS software analysis & Schumm (1956) & 195.47 \\
\hline 18 & Mean basin width (Wb) & $\mathrm{Wb}=A / \mathrm{Lb}$ & Horton (1932) & 60.90 \\
\hline 19 & Basin area $(A), \mathrm{km}^{2}$ & GIS software analysis & Schumm (1956) & 6698.52 \\
\hline 20 & Basin perimeter $(P), \mathrm{km}$ & GIS software analysis & Schumm (1956) & 374.053 \\
\hline 21 & Relative perimeter $(\mathrm{Pr})$ & $\operatorname{Pr}=A / P$ & Schumm(1956) & 17.91 \\
\hline 22 & Length area relation (Lar) & Lar $=1.4^{*} \times A^{0.6}$ & Hack (1957) & 276.52 \\
\hline 23 & Lemniscate's $(k)$ & $k=\mathrm{Lb}^{2} / A$ & Chorley (1957) & 5.7042 \\
\hline 24 & Form factor ratio $(\mathrm{Ff})$ & $\mathrm{Ff}=A / \mathrm{Lb}^{2}$ & Horton (1932) & 0.175 \\
\hline 25 & Shape factor ratio (Rs) & $\mathrm{Sf}=\mathrm{Lb}^{2} / A$ & & 5.704 \\
\hline 26 & Elongation ratio $(\mathrm{Re})$ & $\operatorname{Re}=2 / \mathrm{Lb} \times(A / 0.5)$ & Schumm (1956) & 0.472 \\
\hline 27 & Elipticity index (Ie) & $\mathrm{Ie}=7 i \times \mathrm{VI}^{2} / 4 A$ & & 1.37 \\
\hline 28 & Texture ratio $(\mathrm{Rt})$ & $\mathrm{Rt}=\mathrm{N} \mathrm{l} / P$ & & 9.45 \\
\hline 29 & Circularity ratio $(\mathrm{Re})$ & $\operatorname{Re}=12.57 \times\left(A / P^{2}\right)$ & Miller (1953) & 0.6016 \\
\hline 30 & Circularity ration (Ren) & $\operatorname{Rcn}=A / P$ & Strahler (1964) & 17.90 \\
\hline 31 & Drainage texture $(\mathrm{Dt})$ & $\mathrm{Dt}=\mathrm{Nu} / P$ & Horton (1945) & 19.81 \\
\hline 32 & Compactness coefficient $(\mathrm{Cc})$ & $\mathrm{Cc}=0.2841 \times P / A^{05}$ & Gravelius (1914) & 1.30 \\
\hline 33 & Fitness ratio $(\mathrm{Rf})$ & $\mathrm{Rf}=\mathrm{Cl} / P$ & Melton (1957) & 0.45 \\
\hline 34 & Wandering ratio $(\mathrm{Rw})$ & $\mathrm{Rw}=\mathrm{Cl} / \mathrm{Lb}$ & Smart and Surkan (1967) & 0.877 \\
\hline 35 & Watershed eccentricity $(t)$ & $x=\left[\left(\left|\mathrm{Lcm}^{2}-\mathrm{cm}^{2}\right|\right)\right]^{0,5} / \mathrm{Wcm}$ & Black (1972) & 5.93 \\
\hline 36 & Hydraulic sinuosity index (Hsi), \% & $\mathrm{Hsi}=((\mathrm{Ci}-\mathrm{Vi}) /(\mathrm{Ci}-1)) \times 100$ & & 37.11 \\
\hline 37 & Topographic sinuosity index (Tsi), \% & $\mathrm{Tsi}=((\mathrm{Vi}-1) /(\mathrm{Ci}-1)) \times 100$ & & 62.88 \\
\hline 38 & Standard sinuosity index (Ssi) & $\mathrm{Ssi}=\mathrm{Ci} / \mathrm{Vi}$ & & 1.58 \\
\hline C. & Drainage texture analysis & & & \\
\hline 39 & Stream frequency $(\mathrm{Sf})$ & $\mathrm{Fs}=\mathrm{Nu} / \mathrm{A}$ & Horton (1932) & 1.106 \\
\hline 40 & Drainage density (Dd), $\mathrm{km} / \mathrm{km}^{2}$ & $\mathrm{Dd}=\mathrm{Lu} / \mathrm{A}$ & Horton (1932) & 1.081 \\
\hline 41 & Constant of channel maintenance $\left(\mathrm{km}^{2} / \mathrm{km}\right)$ & $C=1 / \mathrm{Dd}$ & Schumm (1956) & 0.925 \\
\hline 42 & Drainage intensity (Di) & $\mathrm{Di}=\mathrm{Fs} / \mathrm{Dd}$ & Faniran (1968) & 1.107 \\
\hline 43 & Infiltration number (If) & If $=$ Fs $\times$ Dd & Faniran (1968) & 1.29 \\
\hline 44 & Drainage pattern (Dp) & & Horton (1932) & Dn \& Ra \\
\hline 45 & Length of overland flow ( $\mathrm{Lg}), \mathrm{km}$ & $\mathrm{Lg}=A / 2 \times \mathrm{Lu}$ & Horton (1945) & 0.462 \\
\hline D. & Relief characterizes & & & \\
\hline 46 & Height of basin mouth $(z), \mathrm{m}$ & GIS analysis/DEM & - & 1.00 \\
\hline 47 & Maximum height of the basin $(Z), \mathrm{m}$ & GIS analysis/DEM & - & 104.00 \\
\hline
\end{tabular}


Table 1 (continued)

\begin{tabular}{|c|c|c|c|c|}
\hline S. no. & Morphometric parameter & Formula & References & Result \\
\hline 48 & Total basin relief $(H), \mathrm{m}$ & $H=Z-z$ & Strahler (1952) & 103.00 \\
\hline 49 & Relief ratio $(\mathrm{Rhl})$ & $\mathrm{Rhl}=H / \mathrm{Lb}$ & Schumm (1956) & 0.52 \\
\hline 50 & Absolute relief $(\mathrm{Ra}), \mathrm{m}$ & GIS software analysis & & 104.00 \\
\hline 51 & Relative relief ratio, (Rhp) & $\mathrm{Rhp}=H \times 100 / P$ & Melton (1957) & 27.53 \\
\hline 52 & Dissection index (Dis) & $\mathrm{Dis}=H / \mathrm{Ra}$ & Singh and Dubey (1994) & 0.99 \\
\hline 53 & Gradient ratio $(\mathrm{Rg})$ & $\operatorname{Rg}=(Z-z) / L b$ & Sreedevi (2005) & 0.52 \\
\hline 54 & Watershed slope (Sw) & $\mathrm{Sw}=H / \mathrm{Lb}$ & & 0.52 \\
\hline 55 & Ruggedness number (Rn) & $\mathrm{Rn}=\mathrm{Dd} \times(H / 1000)$ & Patton and Baker (1976) & 0.012 \\
\hline 56 & Melton ruggedness number (MRn) & $\mathrm{MRn}=H / A 0.5$ & Melton (1957) & 81.84 \\
\hline 57 & Total contour length $(\mathrm{Ctl}), \mathrm{km}$ & GIS software analysis & - & $37,908.24$ \\
\hline 58 & Contour interval (Cin), $\mathrm{m}$ & GIS software analysis & - & 20 \\
\hline 59 & Slope analysis (Sa) & GIS analysis/DEM & & $1.84-39.13^{\prime}$ \\
\hline 60 & Average slope $(S), \%$ & $S=(Z \times(\mathrm{Ctl} / H)) /(10 \times A)$ & Wentworth (1930) & $0.57 \%$ \\
\hline 61 & Mean slope ratio (Sm) & & Wentworth (1930) & 2.03 \\
\hline 62 & Mean slope of overall basin $(0 \mathrm{~s})$ & $0 \mathrm{~s}=(\mathrm{Ctl} \times \mathrm{Cin}) / A$ & Chorley (1969) & $1.13 \%$ \\
\hline
\end{tabular}

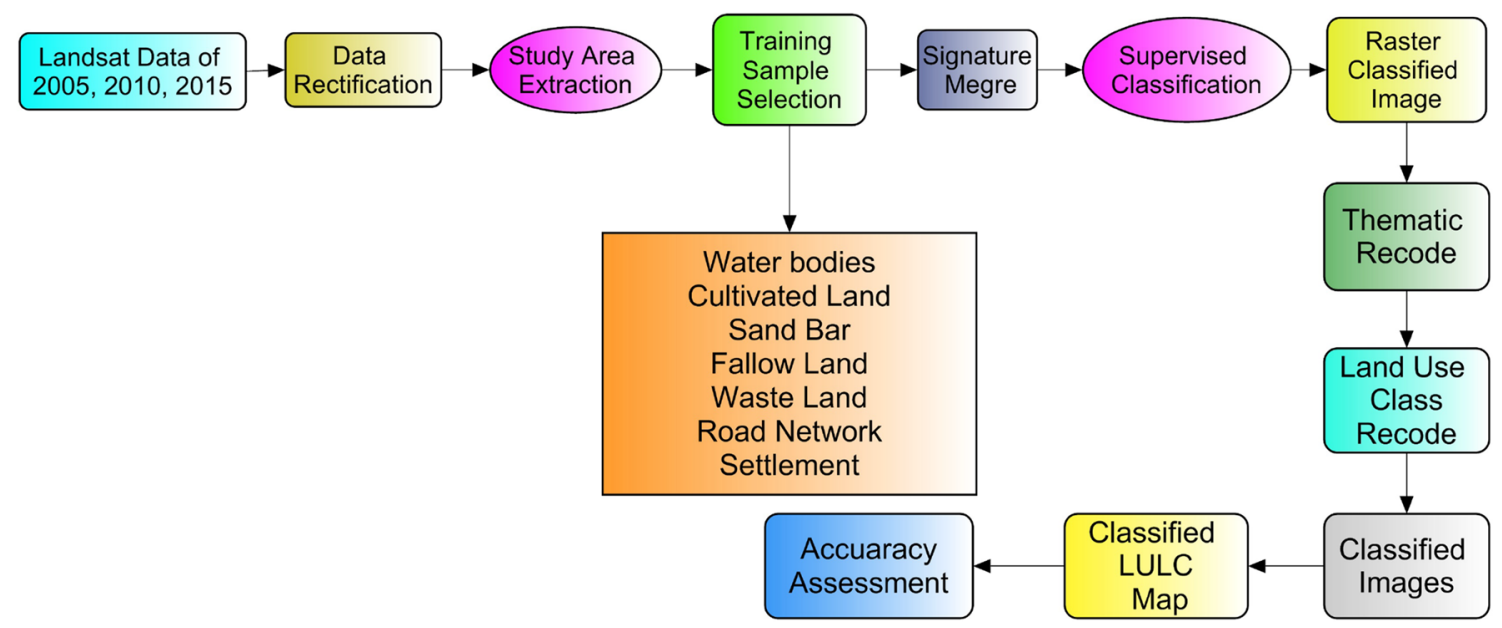

Fig. 4 Methodology of LULC process of Kosi basin

difference in the values 'Lum' because of variation in slope and topography (Strahler 1964).

\section{Stream length ratio (Lur)}

The 'Lur' may be distinct as the ratio of the mean length of the one order to the next lower order of stream segment. The stream length (Lu) shows that the 'Lum' of each consecutive orders of a basin tends to evaluate a direct geometric series with stream length increasing towards higher order of stream. Changes of 'Lur' from one order to another order signifying their late youth stage of geomorphic development (Singh et al. 2014; Rai et al. 2014). During the study, it is calculated that the 'Lur' differs from 0.20 to 0.61 and noted that the 'Lur' between consecutive stream orders of the basin vary due to differences in gradient and topographical characteristics (Sreedevi et al. 2005; Magesh and Chandrasekar 2014; Magesh et al. 2012, 2013). The 'RL' has a vital association with the surface flow discharge and erosional phase of the basin.

\section{Bifurcation ratio $(\mathrm{Rb})$ and weighted mean bifurcation ratio (Rbwm)}

The ' $R b$ ' is the number of the stream units of given order to the number of streams in the subsequent higher order (Strahler (1964). Horton (1945) measured the ' $\mathrm{Rb}$ ' as index of elevation and Strahler (1957) revealed that the ' $\mathrm{Rb}$ ' expresses a small range of difference for diverse areas where the influential structural control dominates. Chow 


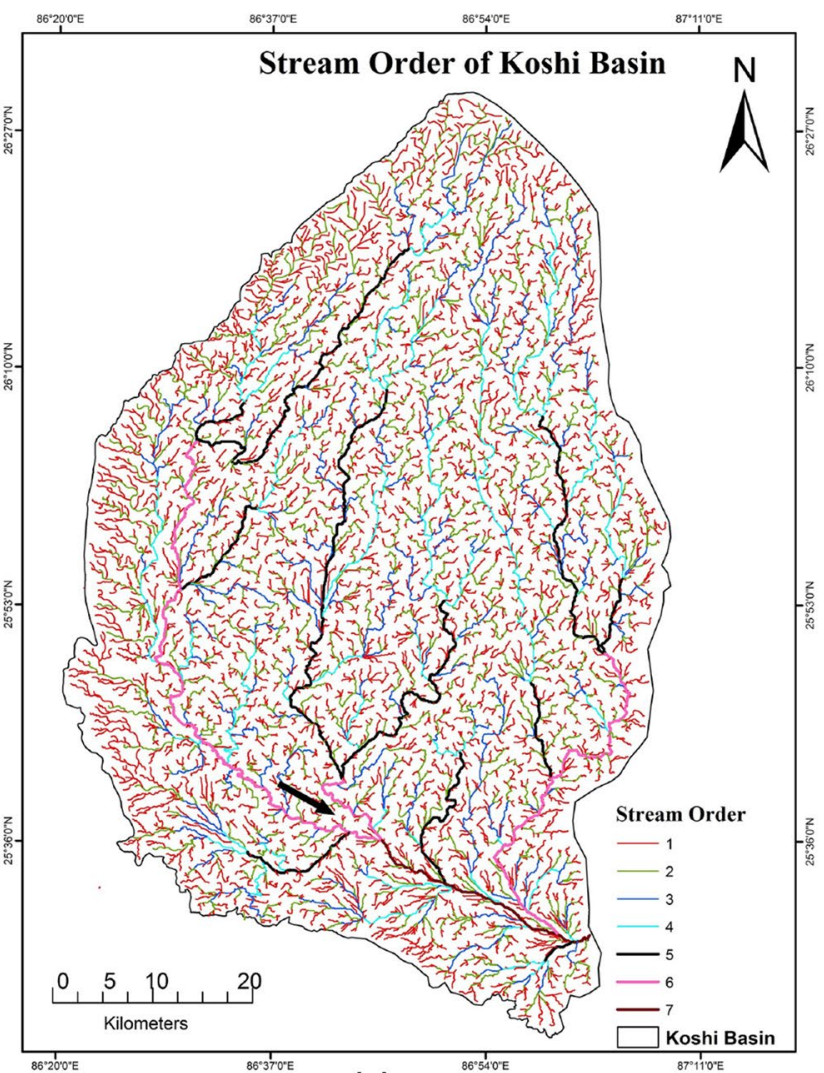

(a)

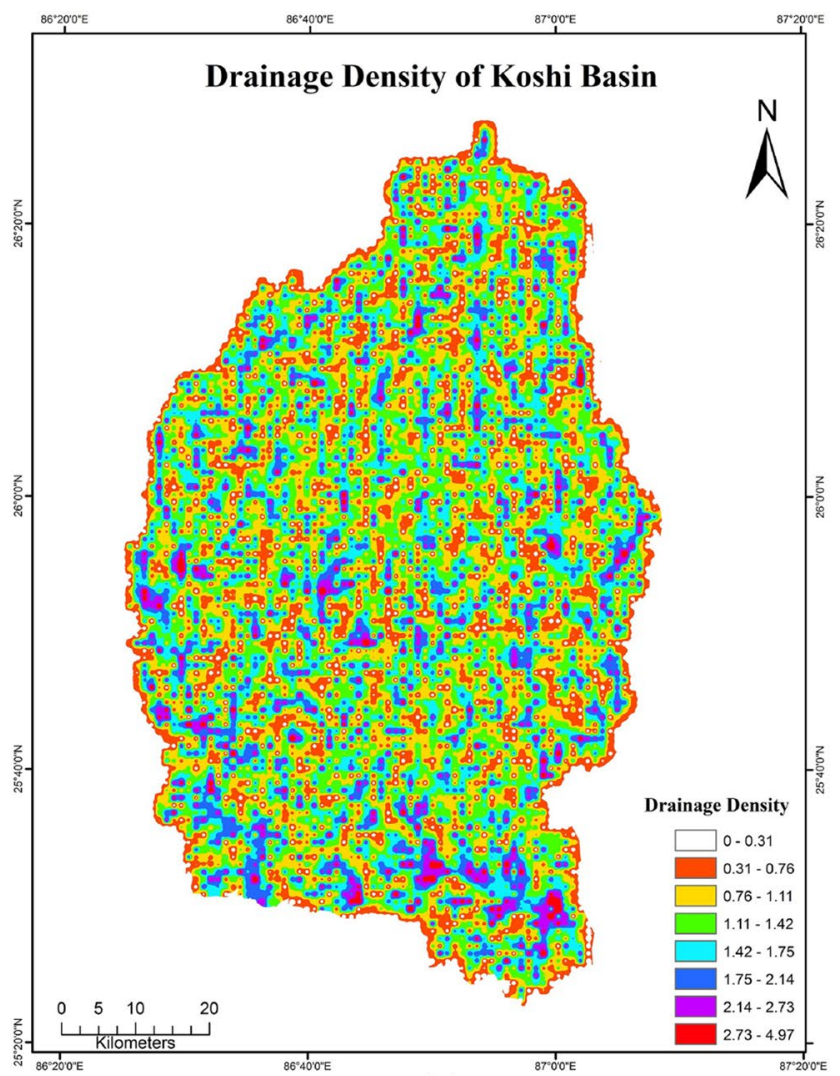

(b)

Fig. 5 Stream order (a) and drainage density (b) of the Kosi basin

Table 2 Stream order, streams number, stream length and mean stream length of lower Kosi basin

\begin{tabular}{lccclc}
\hline $\begin{array}{l}\text { Stream order } \\
(\text { So })\end{array}$ & $\begin{array}{l}\text { Stream count } \\
(\mathrm{Nu})\end{array}$ & $\begin{array}{l}\text { Stream length } \\
(\mathrm{Lu})(\mathrm{km})\end{array}$ & $\begin{array}{l}\text { Mean stream } \\
\text { length (Lum) }\end{array}$ & $\begin{array}{l}\text { Stream length } \\
\text { ratio (Lur) }\end{array}$ & $\begin{array}{l}\text { Bifurca- } \\
\text { tion ratio } \\
(\mathrm{Rb})\end{array}$ \\
\hline 1 & 4038 & 3536.89 & 0.87 & 0.50 & - \\
2 & 1873 & 1773.04 & 0.95 & 0.49 & 2.15 \\
3 & 515 & 879.06 & 1.70 & 0.61 & 3.60 \\
4 & 116 & 537.97 & 4.63 & 0.57 & 4.43 \\
5 & 34 & 309.67 & 9.10 & 0.55 & 3.41 \\
6 & 6 & 171.84 & 28.64 & 0.20 & 5.66 \\
7 & 1 & 35.35 & 35.35 & - & 6.00 \\
Total & 6583 & 7243.82 & 1.10 & - & - \\
\hline
\end{tabular}

(1964) stated that the ' $\mathrm{Rb}$ ' range of ' $3-5$ ' for basin reflects that structural features do not play a main influence on the drainage pattern. The ' $\mathrm{Rb}$ ' between first and second order streams may be considerably higher than the $\mathrm{Rb}$ of higher order streams. This is an indicator of a state of accelerated erosion (Verstappen 1983). In case of floods, the ' $\mathrm{Rb}$ ' has an important role in control over the peakedness of the runoff hydrograph (Chorley 1969) and the stream pattern has not been affected due to the structural influence (Nag 1998). The higher ' $\mathrm{Rb}$ ' value for river basins is the consequence of large variation in frequencies between successive orders and designates the mature topography (Sreedevi et al. 2005; Magesh and Chandrasekar 2014). Normally, the basin produces a sharp peak of discharge when ' $\mathrm{Rb}$ ' value is low while basin yields a low but extended peak flow during high ' $\mathrm{Rb}$ ' value (Agarwal 1998).

The ' $\mathrm{Rb}$ ' is dimensionless unit and normally ranges from 2.15 to 6.0 in the case of Kosi basin. The weighted mean bifurcation ratio (Rbwm) acquired by multiplying the ' $\mathrm{Rb}$ ' for each consecutive pair of stream orders by the total sums 
of streams intricate in the ratio and taking the mean of the sum of these values. Schumm (1956) has used the same calculation to identify the 'Rbwm'. The 'Rbwm 'value of the study area is 2.46 (Table 1 ).

\section{Length of main channel $(\mathrm{Cl})$}

This is the length along the lengthiest channel from the basin upper extent to the boundary of the basin. The main channel length is measured in GIS platform, which is $171.58 \mathrm{~km}$ (Table 1).

\section{Channel index $(\mathrm{Ci})$ and valley index ( $\mathrm{Vi})$}

The drainage channel has divided into number of segments for determination of sinuosity parameter (Miller 1953). The channel and valley lengths are used for calculation of channel index (Ci) and valley index (Vi) and ' $\mathrm{Ci}$ ' and ' $\mathrm{Vi}$ ' value of the Kosi basin is 171.58 and 108.82, respectively (Table 1).

\section{Rho coefficient $(\rho)$}

The 'Rho' coefficient $(\rho)$ is a notable parameter relate drainage density to physiographic growth of a basin which facilitate assessment of storage ability of stream network and hence, a reason of eventual degree of drainage development in river basin (Horton 1945). The climatic, geological, biological, geomorphological, and human induced factors regulate the changes in this parameter. The $\rho$ value of the basin is 0.41 (Table 1) and signifying that it has higher hydrologic storage in floods period.

\section{Basin geometry of the Kosi river}

\section{Length of the basin (Lb)}

Schumm (1956) clear the basin length as the lengthiest measurement of the basin parallel to the principal drainage line. The length of the Kosi basin is $195.4743 \mathrm{~km}$ (Table 1).

\section{Basin area $(A)$, perimeter $(P)$ and width $(\mathrm{Wb})$}

Schumm (1956) recognized a remarkable connection between the total watershed areas and the total stream lengths, which are supported by the contributing areas. Total areal extension of the Kosi basin is $6698.52 \mathrm{~km}^{2}$ while its perimeter and width is 374.05 and $77.42 \mathrm{~km}$, respectively (Table 1).

\section{Length area relation (Lar)}

Hack (1957) identified that for a large number of basins, the stream length and basin area is associated by a simple power function as follows: $\mathrm{Lar}=1.4^{*} \times A^{0.6}$. The 'Lar' of the basin is 276.52 .

\section{Lemniscate's $(k)$}

The Lemniscate's $(k)$ value is used to measure the gradient of the (Chorley et al. 1957). The lemniscate $(k)$ value for the Kosi basin is 5.71 (Table 1), which displays that the basin covers the maximum area in its regions of beginning with large sum of streams of lower order.

\section{Form factor (Ff)}

Form factor (Ff) is the ratio of the basin area to the square of the basin length and used to predict the intensity of a basin of a defined range (Horton 1945; Sreedevi et al. 2013). The 'Ff' of the basin is 0.175 representing no rapid peak discharge at the outlet. If the ' $\mathrm{Ff}$ ' value of the basin is small then the basin will be more elongated and experience lower peak flows of longer duration while the basin with high ' $\mathrm{Ff}$ ' experiences higher peak flows of smaller period.

\section{Elongation ratio $(\mathrm{Re})$}

Elongation ratio $(\mathrm{Re})$ is demarcated as the ratio of diameter of a circle of the same area as the basin to the maximum basin length (Schumm 1956). The variable slopes of basin can be divided with the help of the index of 'Re', i.e., circular (0.9-0.10), oval (0.8-0.9), less elongated (0.7-0.8), elongated (0.5-0.7), and more elongated $(<0.5)$. The 'Re' value of basin is 0.472 , which represents the basin is more elongated (Table 1). The 'Re' close to 1.0 signify the region belongs to very low relief with less structural effects, and the value ranges from 0.8 to 0.6 are related with much steep gradient and high elevation (Strahler 1964).

\section{Texture ratio $(\mathrm{Rt})$ and drainage texture (Dt)}

Schumm (1956) proposed texture ratio (Rt) which depends on the lithology, infiltration ability and relief aspect of the topography and it is stated as the ratio between the first order streams and basin perimeter. The 'Rt' value of the basin is 9.45 and which is moderate in nature (Table 1). Similarly, the ' $\mathrm{Dt}$ ' is a measure of relative channel spacing in a fluvially dissected topography, which is also prejudiced by

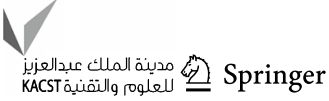


climate, foliage, lithology, soil characteristics, elevation and geomorphic stage of river basin development (Smith 1950; Magesh and Chandrasekar 2014; Magesh et al. 2013). The 'Dt' of the Kosi basin is 21.44 .

\section{Circularity ratio $(\mathrm{Rc})$}

Circularity ratio $(\mathrm{Rc})$ is distinct as the ratio of basin area $(A)$ to the area of a circle having the same perimeter $(P)$ as the basin (Strahler 1964; Miller 1953). It is mainly controlled by geology and structure, relief, slope, climate, stream frequency and length and LULC within the basin area. The 'Rc' ranges from 0.4 to 0.7 indicate sturdily elongated and extremely permeable homogenous geologic materials (Miller 1953). The 'Rc' value (0.60) of the basin validates the Miller's range, which represents the basin shape is elongated in shape, low discharge of runoff and sub-soil condition is extremely permeable (Table 1). The ' $\mathrm{Rc}$ ' is more prejudiced by stream length, stream frequency and basin gradient of various stream orders somewhat than gradient conditions and drainage pattern of the basin (Rai et al. 2014; Magesh and Chandrasekar 2014) and also specifies the dendritic stage of a basin. Low, medium and high values of the 'Rc' show the young, mature, and old phases of the life cycle of the tributary watershed.

\section{Compactness coefficient (Cc)}

The compactness coefficient $(\mathrm{Cc})$ is the ratio of perimeter of basin to circumference of circular area, which equals the basin area (Gravelius 1914). The Cc is independent of size of watershed and dependent only on the slope. The 'Cc' of the basin is 1.30 (Table 1).

\section{Fitness ratio (Rf)}

The fitness ratio ( $\mathrm{Rf})$ is the ratio of main channel length to the basin perimeter, which is a measure of topographic fitness (Melton 1957). The Rf for Kosi basin is 0.46 (Table 1).

\section{Wandering ratio $(\mathrm{Rw})$ and watershed eccentricity $(\tau)$}

Wandering ratio $(\mathrm{Rw})$ is the ratio of the mainstream length to the valley length (Smart and Surkan 1967). In this study, the ' $\mathrm{Rw}$ ' of the basin is 0.88 (Table 1). During the calculation, the basin eccentricity $(\tau)$ of the study area is 5.93 (Table 1).

\section{Sinuosity index (Si)}

Sinuosity index $(\mathrm{Si})$ is the ratio of channel length to down valley distance. In general, its value ranges from 1 to 4 or more. If sinuosity of any river is 1.5 then it is identified as sinuous, and above 1.5 is known as meandering (Miller 1953). The ' $\mathrm{Si}$ ' is a substantial quantitative index for studying the significance of drainage in the development of landforms and valuable for Geomorphologists, Hydrologists, and Geologists. The 'Si' of Kosi river is 1.58 (Table 1).

\section{Drainage texture analysis of Kosi basin}

\section{Stream frequency (Sf)}

The stream frequency ( $\mathrm{Sf}$ ) is the number of stream segments per unit area (Horton 1932, 1945). The 'Sf' of the basin is $1.197 \mathrm{~km}^{2}$ (Table 1) which displays that the increase in stream population is related to that of 'Dd'. It is generally controlled by the lithology of the basin and specifies the texture of the stream network.

\section{Drainage density (Dd)}

The drainage density (Dd) is the stream length per unit area in basin area (Horton 1932, 1945; Strahler 1952, 1958; Melton 1957) and it is a key element of drainage analysis. The 'Dd' is a significant quantitative expression to the study of landform, though a function of climate, lithology and structures and relief history of the area can use as an indirect factors to describe those variables besides the morphogenesis of landform. The 'Dd' of the basin is $1.081 \mathrm{~km} / \mathrm{km}^{2}$ (Fig. 5b), indicating moderate 'Dd' (Table 1). It is recommended that the moderate 'Dd' specifies the basin is moderate permeable sub-soil and dense foliage area (Nag 1998). Slope and relative height are the key morphological aspects controlling $\mathrm{Dd}$. The low 'Dd' value is preferred where basin relief is low, though high ' $\mathrm{Dd}$ ' is chosen where basin relief is high (Strahler 1964) and represents as a significant independent factor for expressing other morphometric elements.

\section{Drainage texture (Dt)}

Drainage texture (Dt) is a valuable concept of geomorphology and reflect about the basic lithology, infiltration capacity and relief of the topography. It is total number of stream segments of all orders per basin perimeter (Horton 1945). The 'Dd' less than two designates very coarse, between 2 and 4 coarse, between 4 and 6 moderate, between 6 and 8 fine and $>8$ very fine ' $\mathrm{Dt}$ '(Smith 1950). The Dt of the basin is 21.44 (Table 1) which express that the category is very fine drainage texture.

\section{Constant of channel maintenance $(C)$}

Schumm (1956) suggested the inverse of 'Dd' or the constant of channel maintenance $(C)$ as a significant aspect of landform. The constant express the per $\mathrm{km}^{2}$ of basin surface 
essential to develop and sustain a channel $1 \mathrm{~km}$ long. It is mainly dependent on the rock form, permeability, climatic regime, foliage cover and relief along with duration of erosion. The ' $C$ ' value designates the comparative size of landforms components in a river basin and has a precise genetic meaning (Strahler 1957). The ' $C$ ' value in the basin is 0.92 and is coming under very less structural disturbances and less runoff condition (Table 1). High ' $C$ ' value in any basin displays the basin area of lower stream order drainages are fairly larger than the sub-basins which have lower $C$ value. Low ' $C$ ' value in the basin reduces length of overland flow $(\mathrm{Lg})$, thus water discharges rapidly as channel flow in scant vegetation cover (Samal et al. 2015).

\section{Drainage intensity (Di)}

The drainage intensity (Di) is the ratio of the ' $\mathrm{Sf}$ ' to the 'Dd' of the basin (Faniran 1968). The study shows a low 'Di' of 1.10 for the Kosi basin (Table 1). The low 'Di' value infers that 'Dd' and 'Sf' have slight consequence on the extent to which the land surface has been lowered by agents of denudation. With these low values of 'Dd', 'Sf' and 'Di', surface runoff is not rapidly removed from the basin, making it extremely susceptible to flooding, gully erosion and landslides.

\section{Infiltration number (If)}

The infiltration number (If) of a basin is the product of the 'Dd' and 'Sf' and describes about the infiltration physiognomies of the basin area. It is inversely proportional to the infiltration capability of the basin (Romshoo et al. 2012). The higher the 'If' value, the lower will be the infiltration and the higher runoff (Table 1). The 'If' value of the study area is 1.29 which specifies that the low infiltration capability and causes more water flow in small time period during the rainfall season (Bhatt and Ahmed 2014).

\section{Drainage pattern (Dp)}

The drainage pattern $(\mathrm{Dp})$ reflects the impact of slope, lithology and structure and helps in recognizing the stage in the cycle of erosion. The 'Dp' presents the characteristics of river basins through drainage texture (Dt). It is possible to deduce the geology of the basin, the strike and dip of depositional rocks, existence of faults and other information about geological structure from drainage patterns. The 'Dt' reveals climate, rock permeability, vegetation, and relief ratio, etc. Dendritic pattern is utmost important pattern developed in a basin composed of fairly similar rock without effect by the underlying geologic structure. If the time of formation of basin is long then the more easily the dendritic pattern is developed (Pareta and Pareta 2011).

\section{Length of overland flow (Lg)}

The length of overland flow $(\mathrm{Lg})$ is the length of flow path, projected to the horizontal, non-channel flow from a point on the stream divide to a point on the neighboring stream channel (Horton 1945). The ' $\mathrm{Lg}$ ' is adjusted to a magnitude suitable to the scale of the first order drainage basin and is approximately equal to one half the reciprocal of the ' $\mathrm{Di}$ '. In this study, the ' $\mathrm{Lg}$ ' value of the basin is $0.462 \mathrm{~km}$ (Table 1), which shows low surface runoff in area.

\section{Relief characteristics of the Kosi basin}

\section{Relief ratio $(\mathrm{Rhl})$}

Total relief of the basin is the difference in the elevation between the highest point and the lowest point on the valley floor of the river basin. Basin relief is a key indicator of a drainage system shown by the elevation (Samal et al. 2015). The 'Rhl' is the ratio between the total relief and the lengthiest measurement of the basin parallel to the main drainage line (Schumm 1956) and it is directly related to the ' $\mathrm{Lg}$ ' and time to peak. The possibility of a close correlation between 'Rhl' and hydrologic characteristics of a basin found that sediments loose per unit area is closely correlated with relief ratios. In the study area, the 'Rhl' is 0.52 (Table 1 ). The area with low to moderate relief and gradient are characterized by moderate value of relief ratios while low 'Rhl' value is generally due to the resistant basement rocks and low degree of basin slope.

\section{Relative relief (Rhp)}

The maximum basin relief is calculated from the highest point on the basin perimeter to the mouth of the stream. Using the basin relief (174 m), a 'Rhl' was computed as proposed by Schumm (1956), which is 0.006 . The 'Rhp' value of the study area is 27.53 .

\section{Ruggedness number (Rn) and Melton ruggedness number (MRn)}

The ruggedness number $(\mathrm{Rn})$ is the product of the basin relief and the 'Di' (Strahler 1958) and combines slope steepness with its length and has implications on the structural complexity and erosion potential of the landforms (Vijith and Satheesh 2006). The ' $\mathrm{Rn}$ ' value of the study area is 0.12 (Table 1). The low 'Rn' of basin suggests that area is less prone to soil erosion and have intrinsic structural intricacy in relation with relief and 'Dd'. 
The MRn is a slope index that delivers specialized depiction of relief ruggedness within the basin (Melton 1957). The 'MRn' of the basin is 81.84 (Table 1) which indicates this basin is debris flood basin, where bed load component dominates sediment under transport.

\section{Dissection index (Dis)}

Dissection index is a factor inferring the degree vertical erosion and explains the phases of landform development in any given physiographic region (Singh and Dubey 1994). Normally, the 'Dis' vary between 0 (complete absence of vertical erosion and hence dominance of flat surface) and 1 (vertical cliffs, it may be at vertical escarpment of hill slope or at seashore). The 'Dis' value of the basin is 0.99 (Table 1), which indicate the area is a moderately dissected.

\section{Gradient ratio $(\mathrm{Rg})$}

Gradient in the steepness of a slope, stated as a proportion between its vertical intervals reduced to unity, and its horizontal equivalent. The outcome achieved in the preceding equation is used to estimate the tangent of the angle of slope of the basin. The ' $\mathrm{Rg}$ ' is a parameter of channel slope, which facilitates calculation of the runoff volume (Sreedevi et al. 2005). The ' $\mathrm{Rg}$ ' value of the study area is 0.52 (Table 1 ), which reveals the mountainous nature of the terrain, where the Kosi river originates.

\section{Slope analysis (Sa) and average slope of the basin $(S)$}

Slope is demarcated by a plane tangent to the topographic surface. Slope of the basin area are acquired from ASTERDEM which is an important feature of the earth's surface system. Maximum slope line is noticeable in the direction of a channel reaching downwards on the ground surface. During the study it is identified that the area is under $1.84^{\circ}-39.13^{\circ}$ slope category (Table 1 ). According to Wenthworth's (1930), erodibility of a river basin can be calculated and equated from its average slope. More the percentage of slopes more are its erosion, if all other things are kept constant. Average slope of the basin is $1.13 \%$ (Table 1).

\section{Assessment of land use land cover (LULC) change in the Kosi basin}

Basin or watershed level planning is inherently concerned with land use issues and their impact on watershed interests, such as stream quality and biological diversity. Watershed has been used as physical, biological, social, economic and political units for the planning and implementation of land management activities. Watershed based land use analysis will play an important role in a sustainable future and proper development of water resource in the basin area.

Land use pattern changes become an essential component in hydrological monitoring and natural resources planning and management (Rawat et al. 2013; Sylla et al. 2012; Vishwakarma et al. 2016). LULC change detection is very vital for proper analysis of landform dynamic during one time to the another time having viable management and also it is an extensive and continuous process through various natural phenomena and human actions, which in turn drive changes that would impact natural ecosystem (Ruiz-Launa and Berlanga-Robles 2003; Turner and Ruscher 2004; Mishra et al. 2014; Mishra and Rai 2016). Valuable information related to land use change can be easily detected through remote sensing data base upon which appropriate planning and decisions can be made in economical way (Franklin 2001). Landsat images in specific have helped in the classification of different landform parameters at a larger scale (Ozesmi and Bauer 2002). Hydrological implications from land use pattern can support to comprehend the changing patterns of water requirement from different actions such as agricultural purpose, domestic and industrial requirements and also used to know the infiltration, recharge and runoff rate of the drainage basin (Singh et al. 2014).

In the present paper, a supervised classification approach was completed to assess the land use pattern and their spatial variation which can be more closely controlled by image processing or image interpreter. This process is generally used when the interpreter has information about the land cover of the study area from other data sources (existing landuse maps or ground truthing, etc.), and it generally gives more accurate results. The outcomes achieved through the study of multi-temporal satellite data of the identical season are diagrammatically shown in Fig. $6 \mathrm{a}-\mathrm{c}$ and data are given in Table 3. Figure 6 depicts LULC status of the Kosi basin in 2005, 2010 and 2015. A general land use categories, i.e., water bodies, cultivable land, vegetation, settlement, fallow land, waste land, settlement, sand bar were interpreted with reference to their water necessity (Fig. 6).

During the classification of the satellite data, both positive and negative changes are identified in the land use land cover pattern in the Kosi basin. During 2005-2015, the vegetation in the basin area has decreased from $4652.40 \mathrm{~km}^{2}$ in 2005 to $1516.20 \mathrm{~km}^{2}$ in 2015 which accounts for $22.63 \%$ of the total covered area. The cultivable land has slightly increased from $329.30 \mathrm{~km}^{2}$ in 2005 to $393.80 \mathrm{~km}^{2}$ in 2015 which accounts for $5.87 \%$ of the total area. It is clearly seen that the settlement area has been dramatically increased from $218.60 \mathrm{~km}^{2}$ in 2005 to $1042.50 \mathrm{~km}^{2}$ in 2015 which accounts for $15.56 \%$ of the total basin area. This reason may be shifting of agricultural land to built-up area and increasing of the population and urban area. The waste land has been increased from $784.20 \mathrm{~km}^{2}$ in 2005 to $1603.90 \mathrm{~km}^{2}$ in 
Fig. 6 Land use land cover (LULC) map of Kosi basin during 2005, 2010 and 2015
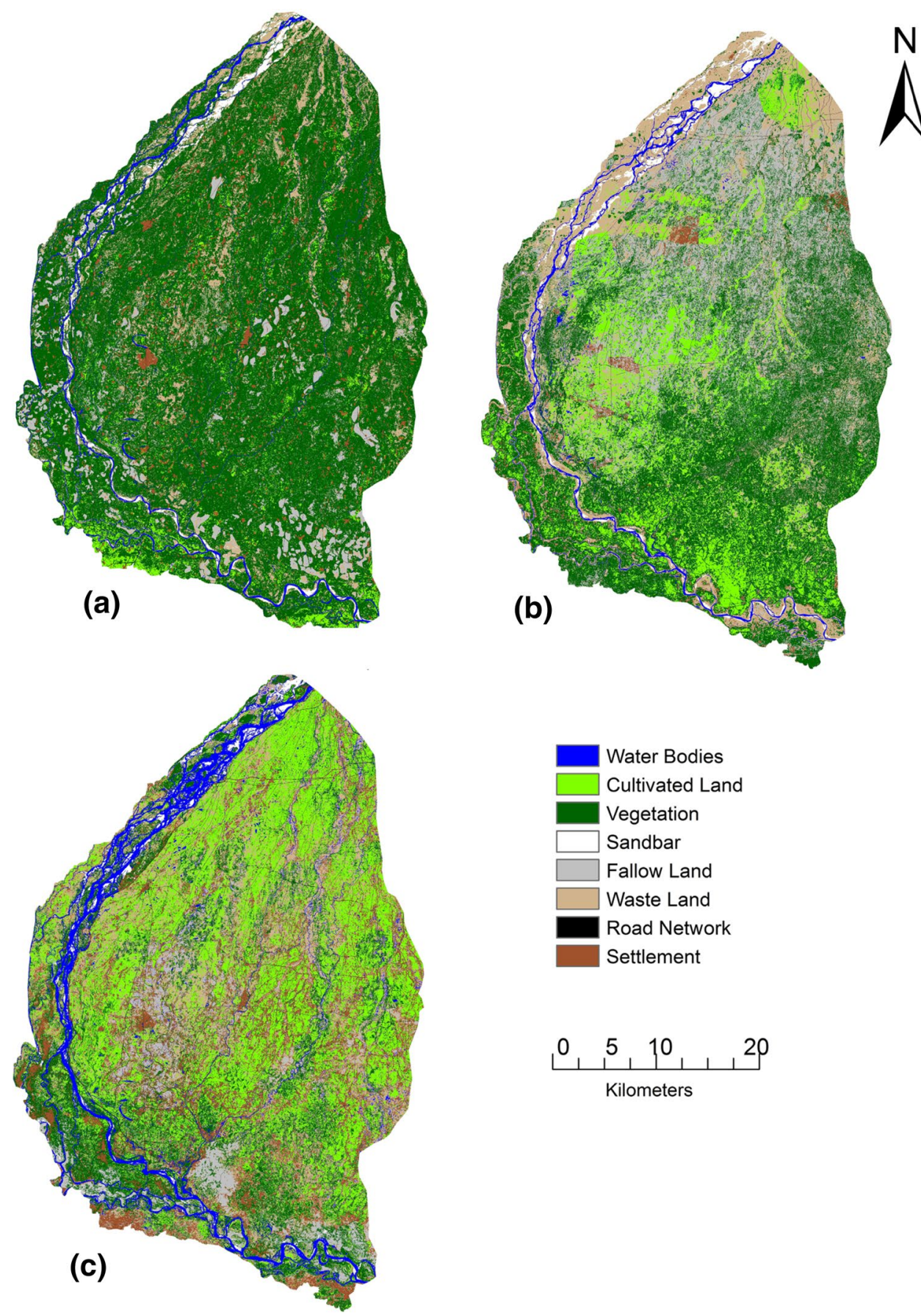

2015 which accounts for $23.94 \%$ of the total basin area. The water bodies of the river basin area have decreased from $178.40 \mathrm{~km}^{2}$ in 2005 to $116.50 \mathrm{~km}^{2}$ in 2015 which accounts for $1.73 \%$ of the total basin area (Table 3 ).

Supervised classification algorithm generated a transition area matrix (Table 4) by evaluating two LULC results of 2005 and 2015. To measure the accuracy of LULC maps interpreted from Landsat TM and ETM+ data, a total of 100 stratified random pixels were produced for
2005 and 2010 data and 100 pixels for the 2015 land cover map. The points were changed to $\mathrm{kml}$ files, to drape on Google Earth data. This was essential to evaluate the outcomes of classification accuracy and change of land cover categories. After classifying LULC types of the Kosi basin area, post classification accuracy calculation have been done to enhance reliability of classified data to the reference data. The reference data were obtained using random sample points, the field experiences and Google earth data. The collected ground truth data were used to

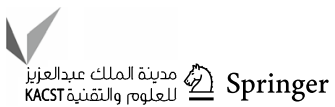


Table 3 Area and change in different land use land cover categories in the Kosi basin in 2005, 2010 and 2015

\begin{tabular}{lccccccccc}
\hline LULC classes & 2005 & Area $(\%)$ & 2010 & Area $(\%)$ & 2015 & Area $(\%)$ & $\begin{array}{l}\text { Changes }(\%) \\
2005-10\end{array}$ & $\begin{array}{l}\text { Changes }(\%) \\
2010-15\end{array}$ & $\begin{array}{l}\text { Changes } \\
(\%) \\
2005-15\end{array}$ \\
\hline Water bodies & 178.4 & 2.66 & 152.7 & 2.3 & 116.5 & 1.7 & -13.53 & -26.08 \\
Cultivable land & 329.3 & 4.69 & 337.4 & 5.03 & 393.8 & 5.87 & +2.44 & +16.69 & +19.55 \\
Vegetation & 4652.4 & 69.6 & 2356.1 & 35.17 & 1516.2 & 22.63 & -49.39 & -35.65 & -67.43 \\
Sand bar & 106.5 & 1.5 & 103.2 & 1.4 & 94.6 & 1.4 & +2.66 & -9.09 & -6.66 \\
Fallow land & 367.3 & 5.4 & 1452.3 & 21.69 & 1826.4 & 27.26 & +301.48 & +25.73 & +404.81 \\
Waste land & 784.2 & 11.9 & 1419.5 & 21.32 & 1603.9 & 23.94 & +81.11 & +12.97 & +104.61 \\
Settlement & 61.8 & 0.98 & 82.7 & 1.23 & 104.6 & 1.64 & +25.51 & +33.33 & +67.34 \\
Road network & 218.6 & 3.35 & 794.6 & 11.86 & 1042.5 & 15.56 & +254.02 & +31.19 & +364.47 \\
Total & 6698.5 & 100 & 6698.5 & 100 & 6698.5 & 100 & - & - \\
\hline
\end{tabular}

Table 4 The transition matrix from 2005 to 2015 (area in $\mathrm{km}^{2}$ )

\begin{tabular}{lllllllll}
\hline 2015 & Water bodies & Cultivated land & Vegetation & Sandbar & Fallow land & Waste land & Settlement & Road network \\
\hline 2005 & & & & & & & & \\
Water bodies & 98.3 & 4.6 & 5.2 & 2.6 & 3.54 & 0.53 & 1.73 & 116.5 \\
Cultivated land & 3.27 & 235.5 & 33.4 & 0.45 & 58.03 & 1.25 & 20.36 & 393.8 \\
Vegetation & 15.83 & 18.04 & 1316.2 & 0.55 & 63.2 & 11.37 & 71.8 & 1516.2 \\
Sandbar & 8.98 & 0.073 & 1.2 & 80.34 & 1.061 & 2.81 & 0.097 & 94.6 \\
Fallow land & 18.17 & 17.37 & 1338.2 & 1.86 & 214.46 & 157.39 & 59.37 & 1826.4 \\
Waste land & 0.84 & 1.29 & 1339.4 & 19.56 & 0.549 & 200.8 & 30.21 & 1603.9 \\
Settlement & 33 & 29.08 & 609.4 & 0.8 & 21.37 & 298.45 & 40.37 & 1042.5 \\
Road network & 0 & 13.34 & 9.4 & 0.34 & 5.09 & 61.5 & 9.93 & 104.6 \\
Total & 178.4 & 329.3 & 4652.4 & 106.5 & 367.3 & 784.2 & 218.6 & 6698.5 \\
\hline
\end{tabular}

Table 5 Kappa statistics and overall accuracy of different years

\begin{tabular}{lll}
\hline Year & Overall accuracy $(\%)$ & Kappa statistics \\
\hline 2005 & 82.50 & 0.745 \\
2010 & 87.50 & 0.838 \\
2015 & 90.00 & 0.866 \\
\hline
\end{tabular}

verify the classification accuracy. Accuracy assessment of the LULC classification outcomes achieved presented an overall accuracy of $82.50 \%$ for $2005,87.50 \%$ for 2010 and $90.00 \%$ for 2015 . The Kappa coefficients for 2005 , 2010 and 2015 maps were $0.745,0.838$ and 0.866 , respectively (Table 5).

\section{Conclusion}

The results achieved in this study proposes that morphometric attributes defining basin geometry as well as shape, length of stream, stream network topology and topography dissection can be well retrieved from ASTER-DEM and accomplished to generate data on stream number and basin relief. Various linear, areal and relief parameters of morphometric evolution were enumerated and deliberated with respect to hydrological process. The spatial variability of the morphometric indication evaluated in the present work is quite important. The hydrological behavior of Kosi basin shall have deep impacts on the flood susceptibility and flood risk in the downstream region of the Kosi river. The morphometric parameters assessed using GIS assisted us to comprehend numerous terrain factors such as nature of the bedrock, infiltration capability, surface runoff, etc., and also shown that the stream channel development is immaterial with the Kosi basin area and their frequency decreases due to the increasing stream order. The change in discharge variation through study of Kosi river morphology and morphometry reveals that the dynamism of river morphology is result of natural processes and also anthropogenic interference. Identification of a suitable hydrological model and simulating the basin area by seeing many topographic attributes would give quantitative relationship between hydrological and 
morphometric indicators. From the above study, it can be understood that the morphometric information of basin are when integrated with the other hydrological characteristics of the river basin, the plan and policy of siting recharge and water-harvesting measures deliver improved groundwater conservation and management plan.

Acknowledgements The authors express their deep sense of gratefulness to USGS for providing Landsat and ASTER data at no cost.

Open Access This article is distributed under the terms of the Creative Commons Attribution 4.0 International License (http://creativecomm ons.org/licenses/by/4.0/), which permits unrestricted use, distribution, and reproduction in any medium, provided you give appropriate credit to the original author(s) and the source, provide a link to the Creative Commons license, and indicate if changes were made.

\section{References}

Abrahams AD (1984) Channel networks: a geomorphological perspective. Water Resour Res 20:161-168

Agarwal CS (1998) Study of drainage pattern through aerial data in Naugarh area of Varanasi district, U.P. J Indian Soc Remote Sens 24(4):129-139

Ali K, Bajracharya RM, Sitaula BK, Raut N, Koirala HL (2017) Morphometric analysis of Gilgit river basin in mountainous region of Gilgit-Baltistan Province, Northern Pakistan. J Geosci Environ Protect 5:70-88

Asode AN, Sreenivasa A, Lakkundi TK (2016) Quantitative morphometric analysis in the hard rock Hirehalla sub-basin, Bellary and Davanagere Districts, Karnataka, India using RS and GIS. Arab J Geosci 9:381. https://doi.org/10.1007/s12517-016-2414-x

Banerjee A, Singh P, Pratap K (2015) Morphometric evaluation of Swarnrekha watershed, Madhya Pradesh, India: an integrated GIS based approach. Appl Water Sci. https://doi.org/10.1007/ s13201-015-0354-3

Bhatt S, Ahmed SA (2014) Morphometric analysis to determine floods in the Upper Krishna basin using Cartosat DEM. Geocarto Int 29(8):878-894. https://doi.org/10.1080/10106049.2013.868042

Black PE (1972) Hydrograph responses to geomorphic model watershed characteristics and precipitation variables. J Hydrol 17:309-329

Chakraborty T, Kar R, Ghosh P, Basu S (2010) Kosi megafan: historical records, geomorphology and the recent avulsion of the Kosi river. Q Int 227(2):143-160

Chorley RJ (1969) Introduction to fluvial processes. Methuen and Co., Limited, London, p 588

Chorley RJ, Donald Malm EG, Pogorzelski HA (1957) A new standard for estimating drainage basin shape. Am J Sci 255:138-141

Chow VT (1964) Handbook of applied hydrology. McGraw Hill Book Company, New York

Dar RA, Chandra R, Romshoo SA (2013) Morphotectonic and lithostratigraphic analysis of intermontane Karewa basin of Kashmir Himalayas, India. J Mt Sci 10(1):731-741

Faniran A (1968) The index of drainage intensity - a provisional new drainage factor. Aust J Sci 31:328-330

Franklin SE (2001) Remote sensing for sustainable forest management. Lewis Publishers, Boca Raton, p 407

Gravelius H (1914) Flusskunde. Goschen Verlagshan dlung Berlin. In: Zavoianu I (ed) Morphometry of drainage basins. Elsevier, Amsterdam
Hack J (1957) Studies of longitudinal stream profiles in Virginia and Maryland. In: U.S. Geological Survey professional paper, 294-B

Hathout S (2002) The use of GIS for monitoring and predicting urban growth in East and West St Paul, Winnipeg, Manitoba, Canada. J Environ Manag 66:229-238

Herold M, Goldstein NC, Clarke KC (2003) The spatio-temporal form of urban growth: measurement, analysis and modeling. Remote Sens Environ 86:286-302

Horton RE (1932) Drainage-basin characteristics. Trans Am Geophys Union 13:350-361

Horton RE (1945) Erosional development of streams and their drainage basins: hydrophysical approach to quantitative morphology. Geol Soc Am Bull 56:275-370

Huggett R, Cheesman J (2002) Topography and the environment. Prentice Hall, Pearson Education, Upper Saddle River, p 274

Lambin EF, Geist H, Lepers E (2003) Dynamics of land use and cover change in tropical regions. Annu Rev Environ Resour 28:205-241

Macka Z (2001) Determination of texture of topography from large scale contour maps. Geografski Vestnik 73(2):53-62

Magesh NS, Chandrasekar N (2014) GIS model-based morphometric evaluation of Tamiraparani sub-basin, Tirunelveli district, Tamil Nadu, India. Arab J Geosci 7:131-141

Magesh NS, Jitheshlal KV, Chandrasekar N, Jini KV (2012) GIS based morphometric evaluation of Chimmini and Mupily watersheds, parts of Western Ghats, Thrissur District, Kerala, India. Earth Sci Inform 5:111-121

Magesh NS, Jitheshal KV, Chandrasekar N, Jini KV (2013) Geographical information system based morphometric analysis of Bharathapuzha river basin, Kerala, India. Appl Water Sci 1-11. http s://doi.org/10.1007/s13201-013-0095-0

Mark DM (1983) Relation between field-surveyed channel network and map-based geomorphometric measures, Inez Kentucky. Ann Assoc Am Geogr 73(3):358-372

Melton MA (1957) An analysis of the relations among the elements of climate, surface properties and geomorphology. Technical report 11. Department of Geology, Columbia University, New York

Mesa LM (2006) Morphometric analysis of a subtropical Andean basin (Tucuman, Argentina). Environ Geol 50(8):1235-1242

Miller VC (1953) A quantitative geomorphic study of drainage basin characteristics on the Clinch Mountain area, Virginia and Tennessee, Project NR 389-402. In: Technical report 3. Department of Geology, ONR, Columbia University, New York

Mishra V, Rai PK (2016) A remote sensing aided multi-layer perceptron-Markov chain analysis for land use and land cover change prediction in Patna district (Bihar), India. Arab J Geosci 9(1):118. https://doi.org/10.1007/s12517-015-2138-3

Mishra VN, Rai PK, Mohan K (2014) Prediction of land use changes based on land change modeler (LCM) using remote sensing: a case study of Muzaffarpur (Bihar), India. J Geogr Inst (Jovan Cvijić SASA, Serbia) 64(1):111-127. https://doi.org/10.2298/ ijgi1401111m

Nag SK (1998) Morphometric analysis using remote sensing techniques in the Chaka sub basin Purulia district, West Bengal. J Indian Soc Remote Sens 26(1-2):69-76

Nautiyal MD (1994) Morphometric analysis of drainage basin, district Dehradun, Uttar Pradesh. J Indian Soc Remote Sens 22(4):252-262

O'Callaghan J, Mark DM (1984) The extraction of drainage networks from digital elevation data. Comput Vis Graph Image Process 28:323-344

Ozdemir H, Bird D (2009) Evaluation of morphometric parameters of drainage networks derived from topographic maps and DEM in point of floods. Environ Geol 56:1405-1415

Ozesmi SL, Bauer ME (2002) Satellite remote sensing of wetlands. Wetlands Ecol Manag 10:381-402 
Pareta K, Pareta U (2011) Quantitative morphometric analysis of a watershed of Yamuna Basin, India using ASTER (DEM) data and GIS. Int J Geomat Geosci 2(1):248-269

Paton PC, Baker VR (1976) Morphometry and floods in small drainage basins subject to diverse hydrogeomorphic controls. Water Resour Res 12:941-952

Rai PK, Mohan K, Mishra S, Ahmad A, Mishra V (2014) A GISbased approach in drainage morphometric analysis of Kanhar river basin, India. Appl Water Sci. https://doi.org/10.1007/s132 01-014-0238-y

Rai PK, Chaubey PK, Mohan K, Singh P (2017a) Geoinformatics for assessing the inferences of quantitative drainage morphometry of the Narmada Basin in India. Appl Geomat 9(3):1-23. https://doi. org/10.1007/s12518-017-0191-1

Rai PK, Mishra VN, Mohan K (2017b) A study of morphometric evaluation of the Son basin, India using geospatial approach. Remote Sens Appl Soc Environ 7:9-20. https://doi.org/10.1016/j.rsas e.2017.05.001

Rawat JS, Biswas V, Kumar M (2013) Changes in land use/cover using geospatial techniques: a case study of Ramnagar town area, district Nainital, Uttarakhand, India. Egypt J Remote Sens Space Sci 16:111-117

Rinaldo A, Rodrı'guez-Iturbe I, Rigon R (1998) Channel networks. In: Jeanloz R, Albee AL, Burke KC (eds) Annual review of earth and planetary sciences, vol 26. Annu Rev, Palo Alto, pp 289-327

Romshoo SA, Bhat SA, Rashid I (2012) Geoinformatics for assessing the morphometric control on hydrological response at watershed scale in the Upper Indus basin. J Earth Syst Sci 121(3):659-686

Ruiz-Luna A, Berlanga-Robles CA (2003) Land use, land cover changes and costal lagoon surface reduction associated with urban growth in northwest Mexico. Landsc Ecol 18:159-171

Samal DR, Gedam SS, Nagarajan R (2015) GIS based drainage morphometry and its influence on hydrology in parts of Western Ghats region, Maharashtra, India. Geocarto Int 30(7):755-778

Schumm SA (1956) Evolution of drainage systems and slopes in bad lands at Perth Amboy, New Jersey. Bull Geol Soc Am 67:597-646

Singh S, Dubey A (1994) Geoenvironmental planning of watershed in India. Chugh Publications, Allahabad, pp 28-69

Singh CS, Singh RL (1973) Changes in the course of rivers and their effects on urban settlements in the Middle Ganga Plain. NGSI, Varanasi

Singh P, Thakur JK et al (2012) Assessment of land use/land cover using geospatial techniques in a semi-arid region of Madhya Pradesh. Geospatial techniques for managing environmental resources (Thakur, Singh, Prasad, Gossel). Springer and Capital Publication, Heidelberg, pp 152-163

Singh P, Thakur J, Singh UC (2013) Morphometric analysis of Morar river basin, Madhya Pradesh, India, using remote sensing and GIS techniques. Environ Earth Sci 68:1967-1977

Singh P, Gupta A, Singh M (2014) Hydrological inferences from watershed analysis for water resource management using remote sensing and GIS techniques. Egypt J Remote Sens Space Sci 17:111-121

Smart JS, Surkan AJ (1967) The relation between mainstream length and area in drainage basins. Water Resour Res 3(4):963-973
Smith KG (1950) Standards for grading textures of erosional topography. Am J Sci 248:655-668

Sreedevi PD, Subrahmanyam K, Ahmed S (2005) Integrated approach for delineating potential zones to explore for groundwater in the Pageru River basin, Cuddapah District, Andhra Pradesh, India. Hydrogeol J 13:534-545

Sreedevi PD, Owais S, Khan HH, Ahmad S (2009) Morphometric analysis of a watershed of South India using SRTM data and GIS J Geol Soc India 73:543-552

Sreedevi PD, Sreekanth PD, Khan HH, Ahmed S (2013) Drainage morphometry and its influence on hydrology in a semi-arid region: using SRTM data and GIS. Environ Earth Sci 70(2):839-848

Srinivasa VS, Govindainah S, Home Gowda H (2004) Morphometric analysis of sub-watersheds in the Pavagada area of Tumkur district South India using remote sensing and GIS techniques. J Indian Soc Remote Sens 32(4):351-362

Srivastava VK (1997) Study of drainage pattern of Jharia coal field (Bihar), India, through remote sensing technology. J Indian Soc Remote Sens 25(1):41-46

Strahler AN (1952) Hypsometric (area-altitude) analysis of erosional topography. Bull Geol Soc Am 63(11):1117-1142

Strahler AN (1957) Quantitative analysis of watershed geomorphology. Trans Am Geophys Union 38:913-920

Strahler AN (1958) Dimensional analysis applied to fluvially eroded landforms. Geol Soc Am Bull 69:279-300

Strahler AN (1964) Quantitative geomorphology of drainage basins and channel networks. In: Chow VT (ed) Handbook of applied hydrology. McGraw Hill Book Company, New York, pp Section 4-11

Sylla L, Xiong D, Zhang HY, Bangoura ST (2012) A GIS technology and method to assess environmental problems from land use/cover changes: Conakry, Coyah and Dubreka region case study. Egypt J Remote Sens Space Sci 15:31-38

Turner MG, Ruscher CL (2004) Change in landscape patterns in Georgia, USA. Landsc Ecol 1(4):251-421

Verstappen H (1983) Applied geomorphology-geomorphological surveys for environmental development. Elsevier, New York, pp $57-83$

Vijith H, Satheesh R (2006) GIS based morphometric analysis of two major upland sub watersheds of Meenachil river in Kerala. J Indian Soc Remote Sens 34:181-185. https://doi.org/10.1007/ BF02991823

Vishwakarma CS, Thakur S, Rai PK, Kamal V, Mukharjee S (2016) Changing land trajectories: a case study from India using remote sensing. Eur J Geogr 7(2):63-73

Weng Q (2001) A remote sensing-GIS evaluation of urban expansion and its impact on surface temperature in the Zhujiang delta, Southern China. Int J Remote Sens 22(10): 1999-2014

Wentworth CK (1930) A simplified method of determining the average slope of land surfaces. Am J Sci 20:184-194

Publisher's Note Springer Nature remains neutral with regard to jurisdictional claims in published maps and institutional affiliations. 